\title{
Development of Learning Design for Mathematics Manipulatives Learning based on E-learning and Character Building
}

\author{
Dwi Sulistyaningsih ${ }^{1 *}$, Purnomo ${ }^{2}$, Abdul Aziz ${ }^{1}$ \\ ${ }^{1}$ Department of Mathematics Education, Universitas Muhammadiyah Semarang, INDONESIA \\ ${ }^{2}$ Department of Mechanical Engineering, Universitas Muhammadiyah Semarang, INDONESIA \\ *CORRESPONDENCE: dwisulis@unimus.ac.id
}

\begin{abstract}
Many types of e-learning are currently available for use in the education sector. E-learning can provide training and education to a large number of students with diverse cultural backgrounds and educational levels. However, e-learning can fail if forced to provide teaching material that exceeds what can be achieved by e-learning. Some people usually do not understand the weaknesses and limitations of e-learning and some of them might expect too much. Social conditions outside the educational regulations play an important role in the formation of student character. Thus the development of positive character can be created through a dynamic relationship between internal and external factors. This study aims to develop the learning design (LD) using mathematics manipulative based on e-learning and character building. The development of LD is carried out in five stages including the initial investigation phase, design, realization, a series of actions consisting of tests followed by evaluation and revision, and field trials of the product. The results show that the completeness of $89 \%$ can be achieved by both individuals and classical after learning using designs that have been developed. The high level of completeness is due to students being able to study independently through material that has been uploaded by the lecturer and if students are not clear they can directly ask the lecturer through the chat facilities provided without waiting for the next meeting. There is a significant difference between the learning outcomes of the experimental class and the control class. The learning outcomes of experimental class students have higher independence and responsibility. Students in the experimental class are able to produce more manipulatives and have better quality.
\end{abstract}

Keywords: manipulatives, e-learning, character building, mathematics

\section{INTRODUCTION}

The practical experience for prospective teachers of mathematics is very important before they really as a teacher. Universities must prepare them with the development of content and pedagogical knowledge that influence classroom practice. Current mathematics studies show that students are frequently decipher information from their experiences. They use concrete manipulatives serve as representations to form a crucial affiliation between procedural and conceptual knowledge (Balka, 1993). Many studies strengthen and use manipulatives in a competency development workshop or forum group discussion for teachers (Bellonio, 2012; Furner et al., 2017; Kelly, 2006; Kontaş, 2016; Muser et al, 2014; Raphael \& Wahlstrom, 1989; Sowell, 1989;

Article History: Received 12 September $2018 \bullet$ Revised 21 November $2018 \bullet$ Accepted 5 December 2018

(C) 2019 by the authors; licensee Modestum Ltd., UK. Open Access terms of the Creative Commons Attribution 4.0 International License (http://creativecommons.org/licenses/by/4.0/) apply. The license permits unrestricted use, distribution, and reproduction in any medium, on the condition that users give exact credit to the original author(s) and the source, provide a link to the Creative Commons license, and indicate if they made any changes. 
Suydam, 1985). They reported that manipulatives are very important in improving their capability to offer both a conceptual model for the abstract mathematical ideas and abstract mathematical process. Students who have experience with manipulative better able to develop clearer mental than those with poor concrete experiences (Heddens, 1986; Moyer, 2001).

Nowadays, the academics used internet as a learning tool, i.e. electronic learning (e-learning) in which the learning content is available online and provides automatic feedback to the learning activities (KaplanLeiserson, 2000; Paulsen, 2003). In Indonesia, education is emphasized not only the cognitive aspects but also on character building. Therefore, universities must be able to provide prospective teachers who have the ability to build student character through the provision of teaching materials and learning design. To meet the needs of the students, e-learning must be driven by good curriculum requirement and learning tools. Design of learning tool that define the characters in an e-Learning is essential to the effectiveness of the understanding of student. In addition, this design effectively helps the use of characters to increase student engagement with lesson content and make the learner experience more interesting. In this work, manipulative learning design has been developed based on e-learning and character building education. This study products are learning tool and learning resource for learning the making of math manipulatives. Learning tools consist of syllabus and Learning Plan (LP). Learning resources are packaged in the form of e-learning which consists of the design of teaching materials, implementation of lesson plans (LPI), and student worksheets.

\section{Why does Character Development Need?}

Efforts have been made to transform conventional into modern learning. The use of modern technology through the development of e-learning-based learning design is the right choice (Chae \& Shin, 2015; Gillani \& Eynon, 2014; Parkes et al., 2015; Sulistyaningsih et al., 2017; Wisneski et al., 2015). More than ten years, United State uses e-learning in education (Chauvot \& Lee, 2015; O'Donnell et al, 2015). Currently, the internet is a noteworthy bit of the learner's diurnal life. It is unavoidable that techniques of teaching and learning should encompass element of e-learning based on the computer and include precise preparation for learning process. The concepts underlying the development of e-learning include independence, learner activeness, learning from problems, and work-based learning (Martens et al, 2004). The e-learning model is based on constructivism (Reiser, 2001) which emphasizes the responsibility of learners in managing their own learning process.

The attitude of discipline and the optimization of the learner's ethical behavior is the essence of character education (Berkowitz \& Hoppe, 2009; Katilmis et al, 2011). The primary foundations of good character are respect, truth, justice, and responsibility (Skaggs \& Bodenhorn, 2006). Equitable cherish, responsibility, and righteousness are the basic propositions of good character (Skaggs \& Bodenhorn, 2006). Character education is not used for rapid rectify on student deviant behavior. This is due to the many factors that influence their behavior include a parentage, sociological, and cultural (Agboola \& Tsai, 2012). This means that the social conditions outside of the educational regulation plays a major role in the student's character building (Agboola \& Tsai, 2012; Romanowski, 2005). Thus it can be justified that character development is the creation of a dynamic relationship between influential internal and external factors to realize positive character growth (Gallien \& Jackson, 2006).

\section{METHOD}

The sample in this study was selected by random sampling from all classes in the 4 th-semester students at mathematics education department of Universitas Muhammadiyah Semarang, Indonesia, academic year of 2016/2017. The development of LD starts with conducting an initial investigation of basic problems, student behavior, and the applied curriculum. The results of the investigation were used as the main consideration in the preparation of learning material. Lecturers and students are involved in the selection of formats, and the initial LD. Furthermore, the prepared learning material is realized as a prototype of learning material, then validation is carried out. The syllabus and LP validation were carried out by three validators consisting of experts in the field of manipulatives, learning planning and senior lecturers in the appropriate fields. While e-learning validation is carried out by experts in the field of multimedia, manipulatives making, and senior lecturers. Revisions are made based on validator suggestions until the prototype is declared to meet valid criteria by the validator. 
Valid prototypes are trialed for their effectiveness in classroom learning. In this trial, the data retrieval instrument consisted of a learning device validation sheet, e-learning validation sheet, student independence questionnaire, student responsibility questionnaire, and student creativity test in the manipulative making.

Data analysis results from teaching material prototype validation consisting of syllabus, LP, and e-learning are calculated using the formula (Bloom \& Hasting, 1981):

$$
V_{a}=\frac{\text { Number of assessment scores }}{\text { Amount of assessment aspects }}
$$

where $V_{a}$ is the average of total validation.

The results of the validator's assessment in each aspect are the average number of scores per aspect of all validators divided by the number of validators. Va values are $\mathrm{Va} \leq 1.5,1.5<\mathrm{Va} \leq 2.5,2.5<\mathrm{Va} \leq 3.5,3.5<\mathrm{Va} \leq$ 4.5 , and $4.5<\mathrm{Va} \leq 5$ for the criteria levels of invalid, poor, fair, valid, and excellent, respectively (Bloom \& Hasting, 1981). The prototype of teaching material can be used without revision if the Va criteria are valid and excellent. If not, then it must be revised based on advice from experts until Va meets the criteria valid or excellent.

Student questionnaire data for independence and responsibility were analyzed by determining the number of students who gave positive and negative responses. Positive responses mean students' answers include always, often, sometimes, ever, and never. with scores for each answer 5, 4, 3, 2, and 1, respectively. A negative response means the opposite condition of a positive response. Validity and reliability of the questionnaire were tested before use. Student creativity test questions were analyzed with validity, reliability, difficulties and distinguishing factors. Validity test is done by using the product moment correlation formula (Arikunto, 2012), while the reliability of test items for student creativity is measured using alpha formula (Arifin, 2013).

Data on the effectiveness of prototypes were analyzed using the completeness test, influence test and different test using t-test. This effectiveness is determined based on three indicators, namely (i) the completeness of student learning in learning, (ii) the influence of independence and responsibility on student learning outcomes, and (iii) differences in learning outcomes treated with untreated classes (Guskey, 2014).

Individual completeness tests are used to determine whether the achievement of basic competencies has reached the set minimum limit, which is 70 . The classical completeness test is used to determine whether the proportion of students who achieve completeness individually has reached the set percentage, which is $80 \%$. Individual and classic completeness were tested using left-handed tests according to the t-test and the Z-test formula, respectively. Independence and student responsibility in terms of creativity in making manipulatives were analyzed using multiple regression. The SPSS program from the Independent Sample t-test menu is used to determine whether there is a difference between the average creativity ability of students treated (i.e. design of e-learning-based learning and character education) with students given learning with conventional models.

\section{RESULTS}

At the initial investigation stage, based on the results of observations and interviews, the data obtained shows that learning still uses traditional methods, lecturers deliver material through lectures and provide tasks to be done at home. In addition, the initial investigation also shows that students need guidance several times to be able to complete the assignments given by the lecturer. Lecturers do not have enough time to discuss directly with students so that it can cause difficulties for students to consult in completing assignments. This condition causes manipulatives produced by students lacking both in quality and quantity. The results of this interview confirmed the results of the questionnaire for students' perceptions of the implementation of learning to make mathematical manipulatives. Learning approaches and strategies are considered bad because the strategies used by the lecturers are not in accordance with the material being taught. In addition, the assignments to be done at home given by the lecturer have not been able to improve students' creativity and independence. So it is necessary to develop a learning designs that can solve existing problems.

The draft of learning design consisting of the syllabus, LP, and teaching materials has been produced at the design stage. The design of learning using e-learning is in line with Horton's idea (Harton, 2006) which states that e-learning as an application of information technology and computers can create an experience in student learning. The e-learning that has been made is equipped with lecture material containing instructional material consisting of examples of the tool making design proposal, learning implementation 


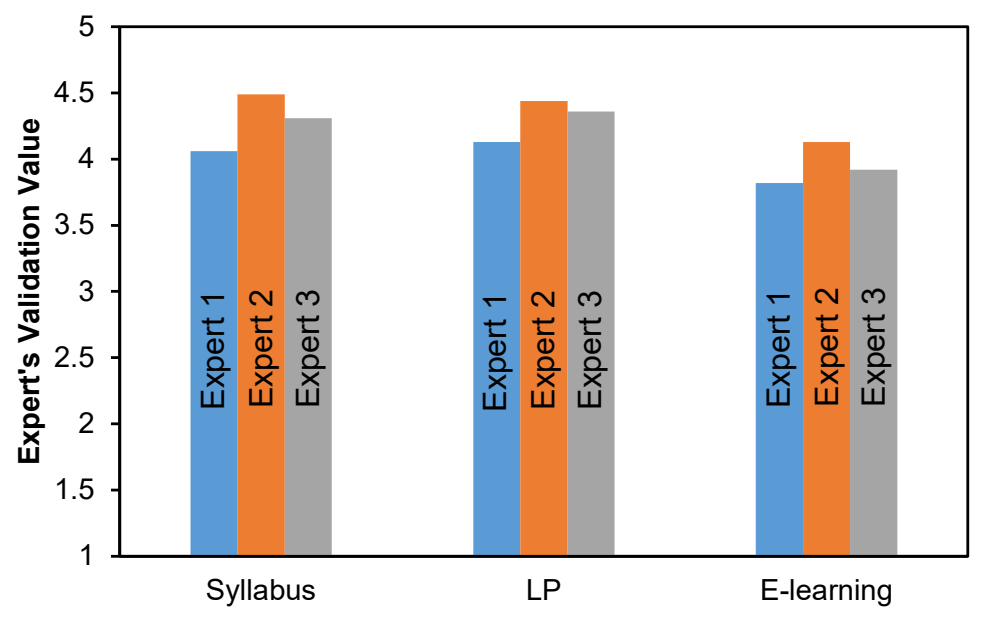

Figure 1. The validity level of the instructional design document

plan using manipulatives, and Student Worksheet (SWs) utilizing manipulatives. To further increase the productivity of students in manipulatives making, e-learning has also been equipped with video manipulatives making that can be used the student reference in the manipulatives manufacture. Students can consult the manipulatives design made through the chat facility. The learning design in the form of e-learning consists of an introduction (instructional use, semester learning plan, assessment instrument), and learning activities (final ability of learning, learning materials, group division, tasks, online discussion forum, video manipulatives making, reports and tasks as well as learning evaluations). The e-learning has been designed for student-centered learning so that they are more independent and responsible in the learning process.

The prototype of an instructional design that has been adapted to the principles and characteristics of learning has been produced at the realization stage. This prototype is a product development that has been produced and ready for expert validation. Based on the validation results, syllabus, LP and e-learning made have met the valid criteria. These validation results are all included in either category, meaning the prototype of the learning design of manipulatives can be used with little revision. The expert's validation results from three validators are presented in Figure 1.

Of the seven tested questions, six are valid and one is invalid. While the distribution of difficulty level of the seven problems are 2 easy, 4 medium and 1 difficult criteria question. The results of the reliability test show that the value of $\mathrm{r} 11=0.856$, which means the problem has a high reliability. The result of experimental class normality test and control class showed $\operatorname{sig}=0.896$ and $\operatorname{sig}=0.484$, respectively. Normality test result questionnaire independence and student responsibility are shown by the value of sig $=0.204$ and $\operatorname{sig}=0.235$, respectively. This result shows that the value of Sig $\geq 0.05$ means that the learning result of the students of experimental class, control class, as well as the independence and responsibility of the students are normally distributed.

The analysis of classical completeness with the minimum limit set 70 has been done and obtained the result that as many as $24(89 \%)$ students reach the completeness of the 27 students who took the test. Lefthanded proportion test results show that the z-count value equal to 1.169 greater than $\mathrm{z}$-table (0.997). This means that the results of student learning that gets a value of $\geq 70$ greater than the proportion set at $80 \%$. The results of experimental learning design as presented in Figure 2 shows that the percentage of students who get the most value compared with the unfinished. By using SPSS, an analysis of the influence of independence and responsibility to student learning outcomes is presented in Table 1. 


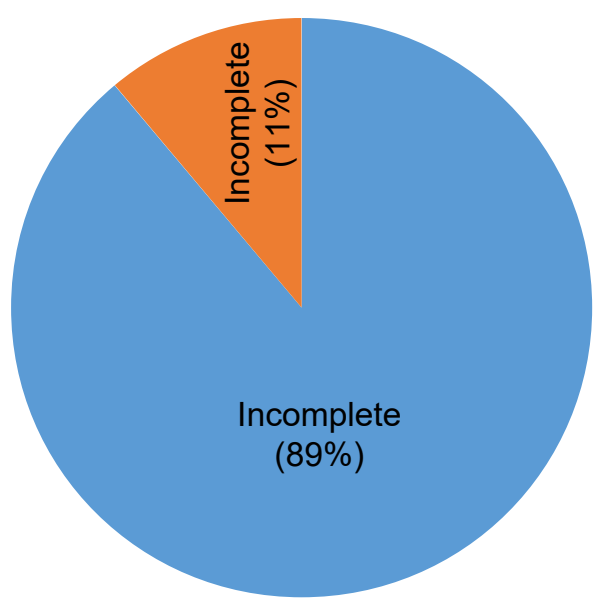

Figure 2. Creativity test results of experiment class

Table 1. The effect of independence and responsibility to student learning outcomes Coefficients $^{\mathrm{a}}$

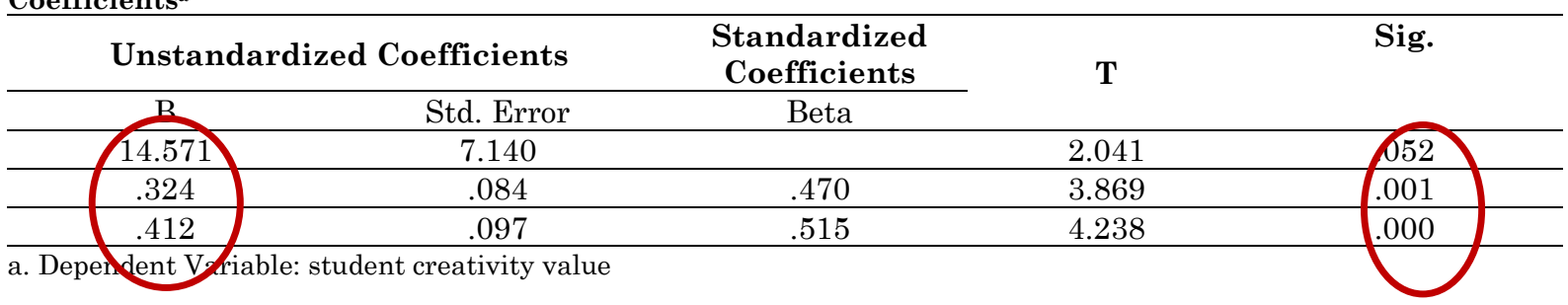

Table 2. The effect of independence and responsibility to student learning outcomes

ANOVAa

\begin{tabular}{|c|c|c|c|c|c|c|}
\hline & Model & Sum of Squares & df & Mean Square & $\mathbf{F}$ & Sig. \\
\hline \multirow{3}{*}{1} & Regression & 414.283 & 2 & 207.142 & 37.282 & \\
\hline & Residual & 133.346 & 24 & 5.556 & & \\
\hline & Total & 547.630 & 26 & & & \\
\hline
\end{tabular}

a. Dependent Variable: value creativity ability

b. Predictors: (Constant): student activity, learning independence

From device trials, it can be found that the significance of independence and student responsibility is 0.001 and 0,000, respectively. This means that learning outcomes are influenced by students' independence and responsibility. From multiple regression test obtained by equation of double regression $\mathrm{Y}=0,324 \mathrm{X} 1+0,412 \mathrm{X} 2$ $+14,571$ which means if independence increase one unit hence student learning result equal to 0,324 and if student responsibility increase one unit hence student learning result increase equal to 0,412. From the linearity test, the value of $\mathrm{sig}=0.000<0.05$, means that the equation is linear, or, the independence and responsibility of students have a positive effect on student learning outcomes. Analysis using SPSS is presented in Table 2.

The test results with SPSS on student learning outcomes showed that he was strongly influenced by the independence and motivation of students (75\%), while the influence of other factors was only about $25 \%$. The average difference test results show that the sig value in the Levene's Test for Equality of Variances is 0.318 , this value is greater than the specified sig value of 0.05 . This means that the experimental and control class data are homogeneous. While the results of the analysis of the two-party test using the Independent-Sample t-test is presented in Table 3 . 
Table 3. Average experimental class test results and control. F indicates the variance of homogeneity

\section{Levene's Test \\ for Equality}

of Variances t-test for Equality of Means

Sig. (2- Mean Std. Error Interval of the tailed) Difference Difference Difference Lower Upper

\begin{tabular}{|c|c|c|c|c|c|c|c|c|c|c|}
\hline \multirow{2}{*}{$\begin{array}{c}\text { student } \\
\text { creativity } \\
\text { value } \\
\end{array}$} & $\begin{array}{c}\text { Equal } \\
\text { variances } \\
\text { assumed } \\
\end{array}$ & 1.015 & .318 & 5.472 & 54 & .000 & 7.221 & 1.319 & 4.575 & 9.867 \\
\hline & $\begin{array}{c}\text { Equal } \\
\text { variances } \\
\text { not assumed }\end{array}$ & & & 5.498 & 53.816 & .000 & 7.221 & 1.313 & 4.588 & 9.854 \\
\hline
\end{tabular}

Table 4. Average experimental class test results and control

\begin{tabular}{cccccc}
\hline \multicolumn{2}{c}{ Class } & N & Mean & Std. Deviation & Std. Error Mean \\
\hline \multirow{2}{*}{ value of creativity experiment } & 27 & 75.7037 & 4.58941 & .88323 \\
\cline { 2 - 5 } & control & 29 & 68.4828 & 5.23464 & .97205 \\
\hline
\end{tabular}

From Table 3, the student creativity for equal variances assumed shows a sig (2-tailed) value equal to 0.000 and 0.05 lesser than the specified significance level. This means that there are differences in the average of student learning outcomes using e-learning-based learning design and character education with learning outcomes whose learning does not use the learning design (conventional). Based on this test, the average value between the experimental class and the control class is presented in Table 4 where N shows the number of samples. It can be seen that the average of experimental class (class 1) and control class (class 2) is 75.70 and 68.48 , respectively. This means the average grade value that uses learning-based learning design and character education is better than the conventional class.

\section{DISCUSSION}

Based on the expert assessment, the design of the learning that has been made has met the valid criteria, with the average value for syllabus and LP is 4.29 and 4.31, respectively, with both valid criteria. This means that the syllabus and LP created can be used without revision. This excellent assessment is attributed to (i) the established syllabus meets the complete elements, (ii) has a suitability between the course descriptions and the learning objectives to be achieved, and (iii) has the conformity between the expected learning outcomes and the material which exists. In addition, the use of learning methods has been adapted to the needs of each meeting. The lecture activities are clearly planned between the activities to be undertaken by lecturers and students. Each learning activity is also based on character education that is clearly listed in the syllabus and LP made. In addition, syllabus and LP also come with the allocation of time allocation that has been adjusted to the depth and complexity of the material to be delivered. The advice of the validator for syllabus and LP is as follows: (i) syllabus and LP should be kept in the standard templates that can be viewed at the time of manufacture and when the revision is made, (ii) LP should be completed with assessment instruments containing the grid questions and assessment guidelines.

Validator states that e-learning is valid (3.9), meaning that e-learning can be used without revision. This is due to (i) e-learning being made with a very interesting cover and content appearance, (ii) e-learning has well-ordered and clear content, (iii) links provided for both forum and chat facilities are very accessible, (iv) the material presented has clarity of content as well as good sentence and grammatical arrangements, (v) elearning developed with assignments and discussion facilities that can increase student participation, activeness and motivation in learning, (vi) collection of tasks through e-learning is designed using the upload time limit to make students more disciplined and have high responsibility so that the level of student independence increases, (vii) e-learning designed learning model that can be the interaction between lecturers and students through using forum facilities, and chat, (viii) e-learning is designed with scattered systematics, and has a clear logical flow. The results of this expert validation are consistent with previous work (Nieveen, 2007; Sulistyaningsih, 2017) who reported that a learning material shows valid if it meets (i) developed 
material based on strong theoretical rationale; (ii) there is consistency in the interval between components of the developed learning material.

The design of learning has reached the completeness of individual and classical completeness that reached $89 \%$. This completeness is achieved because students can learn independently through the material that has been uploaded by the lecturer and if the student is not clear can directly ask the lecturer through the chat facility provided without waiting for the next meeting. The material that has been completed with the example causes the students to more easily make proposals and design manipulatives. In addition, examples of how to create manipulatives made a video will facilitate students in completing manipulatives that are made. Some of these things that make students can achieve individual mastery and classical.

The independence and responsibilities of students have a strong effect on learning outcomes. This is due to the e-learning design already equipped with the tasks accompanied by examples of completion. In addition, e-learning also facilitates students to be able to directly communicate and discuss with lecturers. There is a significant difference between experimental class learning result and control class because the form of elearning based learning is able to solve student problem in consultation to the lecturer. Through e-learning, whenever students can convey problems and lecturers can easily manage the time to provide solutions to student problems. In addition, the students are trained to be more responsible for the task given by the lecturer. This condition is what causes students to produce more products and have a better quality.

\section{CONCLUSION}

The LD development is a good idea. The concept of LD development process that has been established in the study has produced teaching materials that can be used to meet the needs of students in learning to create mathematics manipulatives. LD's development process offers a proven effective methodology for learning design and should be considered an integral part of the creation of effective learning based on e-learning and character building. Learning materials uploaded on the internet provide a learning framework for the development of student interventions delivered through the internet and the strengthening of good character underlying learning practices. The nature of strong independence and a high sense of responsibility in completing the task is the impact of mathematics learning based on e-learning and character building. This learning design is very appropriate in order to foster the attitude of independence and responsibility of students to the completion of tasks. Time can be utilized effectively which ultimately increase student productivity. By using the developed learning design, behaviors for active joint learning are available. Better student independence and responsibility can improve student learning outcomes.

\section{Disclosure statement}

No potential conflict of interest was reported by the authors.

\section{Notes on contributors}

Dwi Sulistyaningsih - Dept. of Mathematics Education, Universitas Muhammadiyah Semarang, Indonesia.

Purnomo - Dept. of Mechanical Engineering, Unievrsitas Muhammadiyah Semarang, Indonesia.

Abdul Aziz - Dept. of Mathematics Education, Universitas Muhammadiyah Semarang, Indonesia.

\section{REFERENCES}

Agboola, A., \& Tsai, K. C. (2012). Bring Character Education into Classroom, European Journal of Educational Research, 1(2), 163-170. https://doi.org/10.12973/eu-jer.1.2.163

Arifin, Z. (2013). Evaluasi Pembelajaran. Bandung: PT Remaja Rosdakarya.

Arikunto, S. (2012). Prosedur Penelitian Suatu Pendekatan Praktek. Jakarta: Rineka Cipta

Balka D. (1993). Making the connections in mathematics via manipulatives. Contemporary Education, 65, 1923.

Bellonio, J. L. (2012). Multi-Sensory Manipulatives in Mathematics: Linking the Abstract to the Concrete. Yale-

New Haven Teachers Institute. Retrieved on 15.02 .2016 from

http://www.yale.edu/ynhti/curriculum/units/2001/6/01.06.12.x.html 
Berkowitz, M. W., \& Hoppe, M. (2009). Character education and gifted children. High Ability Studies, 20(2), 131-142. https://doi.org/10.1080/13598130903358493

Bloom, M., \& Hasting. (1981). Methods Grading in Summative Evaluation. New York: McGraw-Hill

Chae, S. E., \& Shin, J.-H. (2015). Tutoring styles that encourage learner satisfaction, academic engagement, and achievement in an online environment. Interactive Learning Environments, 24(6), 1-15. Retrieved from https://www.tandfonline.com/doi/abs/10.1080/10494820.2015.1009472?journalCode=nile20

Chauvot, J., \& Lee, M. M. (2015). Online instruction about integration of science and mathematics with middle-grades teachers: Four years in and aiming for sustainability. The Internet and Higher Education, 24, 46-52. https://doi.org/10.1016/j.iheduc.2014.09.004

Furner, J. M. M., \& Worrel, N. L. (2017). The Importance of Using Manipulatives in Teaching Math Today. Transformations, 3(1), Article 2. Retrieved from https://nsuworks.nova.edu/cgi/viewcontent.cgi?article= 1013\&context=transformations/

Gallien, L. B., \& Jackson, L. (2006). Character development from African-American perspectives: toward a counternarrative approach. Journal of Education \& Christian Belief, 10(2), 129-142. https://doi.org/10.1177/205699710601000207

Gillani, N., \& Eynon, R. (2014). Communication patterns in massively open online courses. Internet and Higher Education, 23, 18-26. https://doi.org/10.1016/j.iheduc.2014.05.004

Guskey, T. R (1982). The effectiveness of mastery learning Strategies in Undergraduate Education Courses. The Journal of Educational Research, 78, 1983, published on line des 2014, pp. 210-214. https://www.tandfonline.com/doi/abs/10.1080/00220671.1983.10885452

Heddens, J. (1986). Bridging the gap between the concrete and the abstract. Arithmetic Teacher, 33/6, 14-17. Retrieved from https://eric.ed.gov/?id=EJ332096

Horton, W. (2006). E-learning by Design. San Francisco: Pfeiffer.

Kaplan-Leiserson, E. (2000). Glossary. Retrieved on March 10, 2018 from http://www.learningcircuits.org/ glossary.html

Katilmis, A., Eksi, H., \& Öztürk, C. (2011). Efficiency of social studies integrated character education program. Educational Sciences: Theory \& Practice, 11(2), 854-859. Retrieved from https://eric.ed.gov/?id=EJ927380

Kelly, C. A. (2006). Using manipulatives in mathematical problem solving: a performance-based analysis. The Montana Mathematics Enthusiast, 3(2), 184-193. Retrieved from https://scholarworks.umt.edu/tme/vol3/iss2/6/

Kontaş, H. (2016). The Effect of Manipulatives on Mathematics Achievement and Attitudes of Secondary School Students. Journal of Education and Learning, 5(3), 10-20. https://doi.org/10.5539/jel.v5n3p10

Martens R. L., Gulikersw, J., \& Bastiaensw, T. (2004). The impact of intrinsic motivation on e-learning in authentic computer tasks. Journal of Computer Assisted learning, 20, 368-376. https://doi.org/10.1111/j.1365-2729.2004.00096.x

Moyer, P. S. (2001). Are we having fun yet? How teachers use manipulatives to teach mathematics. Educational Studies in Mathematics, 47, 175-197. https://oi.org/10.1023/A:1014596316942

Musser, G. L., Peterson, B. E., \& Burger, W. F. (2014). Mathematics for Elementary Teachers: A Contemporary Approach, 10th Edition, Wiley. Retrieved from https://www.wiley.com/en-us/Mathematics + for + Elementary+Teachers\%3A+A+Contemporary+Approach\%2C+10th+Edition-p-9781118457443

Nieveen, N. (2007). An Introduction to Educational Design Research. Proceedings of the Seminar Conducted at the East China Normal University, Shanghai. Retrieved from https://research.utwente.nl/en/ publications/an-introduction-to-educational-design-research-proceedings-of-the

O'Donnell, E., Lawless, S., Sharp, M., \& Wade, V. P. (2015). A review of personalised e-learning: Towards supporting learner diversity. International Journal of Distance Education Technologies, 13(1), 22-47. https://doi.org/10.4018/ijdet.2015010102

Parkes, M., Stein, S., \& Reading, C. (2015). Student preparedness for university e-learning environments. The Internet and Higher Education, 25, 1-10. https://doi.org/10.1016/j.iheduc.2014.10.002

Paulsen, M. F. (2003). Online Education and Learning Management Systems. Global e-learning in a Scandinavian perspective. Oslo: NKI Forlaget. Retrieved from http://www.irrodl.org/index.php/irrodl/ article/view/202/284

Plomp, T. (1997). Educational and Training System Design. Enschede, Netherlands: Twente University. 
Raphael, D., \& Wahlstorm, M. (1989). The influence of instructional aids on Mathematics achievement. Journal for Research in Mathematics Education, 20, 173-190. https://doi.org/10.2307/749281

Reiser, R. (2001). A history of instructional design and technology. Part 2: a history of instructional design. Educational Technology, Research and Development, 49, 57-67. https://doi.org/10.1007/BF02504928

Romanowski, M. H. (2005). Through the eyes of teachers: High school teachers' experiences with character education. American Secondary Education, 34(1), 6-23.

Skaggs, G., \& Bodenhorn, N. (2006). Relationships between implementing character education, student behavior, and student achievement. Journal of Advanced Academics, 18(1), 82-114. https://doi.org/10.4219/jaa-2006-345

Sowell, E. (1989). Effects of Manipulative Materials in Mathematics Instruction. Journal for Research in Mathematics Education, 20(5), 498-505. https://doi.org/10.2307/749423

Sulistyaningsih, D., Mawarsari, V. D., Hidayah, I., \& Dwijanto. (2017). Manipulatives Implementation For Supporting Learning Of Mathematics For Prospective Teachers. Journal of Physics: Conference Series, 824 012047. https://doi.org/10.1088/1742-6596/824/1/012047

Suydam, M. N. (1985). Research on Instructional Materials for Mathematics, ERIC Clearinghouse for Science, Mathematics and Environmental Education, Columbus, OH. (ERIC Document Reproduction Service No. 276 569). Retrieved from https://eric.ed.gov/?id=ED276569

Wisneski, J. E., Ozogul, G., \& Bichelmeyer, B. A. (2015). Does teaching presence transfer between MBA teaching environments? A comparative investigation of instructional design practices associated with teaching presence. The Internet and Higher Education, 25, 18-27. https://doi.org/10.1016/j.iheduc.2014.11.001 